\title{
EVALUATION OF SOME COMPOUNDS FROM PLANT ORIGIN FOR CONTROLLING SESAMIA CRETICA LED. IN MAIZE UNDER FIELD CONDITIONS
}

\author{
YACOUB, SH. S. ${ }^{1}$, AMANY S. EL-HEFNY ${ }^{1}$ AND RASHA A. EL-HOSARY ${ }^{2}$ \\ 1. Plant Protection Research Institute, ARC, Dokki, Giza \\ 2. Fac. of Agric., Benha University
}

(Manuscript received 10 November 2009 )

\begin{abstract}
Dodonia leaves and Sour orange (water and acetone extracts) in addition to some compounds derived from plant origin were evaluated in controlling Sesamia cretica throughout early summer season 2009. The treatments which caused the best results against $S$. cretica egg-masses, larv ae, number of dead hearts were Natcom 40 (jojoba oil) and Tresser, water dodonia extract and sour orange extracted in petrolum ether. Subsequently, gained the highest yield of 26.7 ardab / feddan. Data showed that a significant negative correlation between yield and each of $S$. cretica traits. The composition of the experimental plants were obtained from some scientific sites on the wide world web.
\end{abstract}

\section{INTRODUCTION}

Maize (Zea mays L.) is a basic food for the majority of the Egyptian farmers and it is considered one of the most important cereal crops in Egypt. Green plants are used as food for large number of farm animals and rabbits.

In Egypt, maize plants are subjected in infestation with a different species of insect pests, of which the corn borer, Sesamia cretica Led. (Lepidoptera: Noctuidae) may be, considered the most derious one as infestation in the seedling stage (Awadallah, 1974).

In order to avoid the hazards caused to the environment, due to the repeated use of traditional chemical insecticides that are commonly used for corn borers' control. It is necessary to use of natural products mainly plant extracts which proof to have deleterious effects on target insects El-Sayed (1982), Awadallah et al., (1984).

The effect of water extract of dedonia and turnip against $2^{\text {nd }}$ and $4^{\text {th }}$ larval instars of Spodoptera littoralis were investigated under laboratory conditions as a toxic activity and antifeedants Yacoub and El-Hefny (2008) \& El-Hefny and Yacoub (2008). 


\section{MATERIALS AND METHODS}

\section{Preparation of material}

Two plants and three commerecial products were chosen in the present experiment to test their toxic activity against the different stages of $S$. cretica in the field. The scientific and English name of the extracted plant and their used parts are shown in the following table:

\begin{tabular}{|l|l|l|}
\hline Scientific name & English name & Part used \\
\hline Dodonaea viscoza & Dodonia & Leaf \\
\hline Citrus aurantium v. amara & Sour orange & pulp \\
\hline
\end{tabular}

Dodonia leaves were cleaned and washed by water then air dried in the laboratory Afifi et al. (1988), Emara et al., (1994) and Yacoub (2006), Extracts were prepared by adding $500 \mathrm{ml}$ of each of boiling water, acetone and petroleum ether to 50 gm of ground parts then stirred for 15 minutes in high electric blender after stoppering the container tightly. While, pulp of sour orange fruits were squeezed without seeds and extracted by the last mentioned solvents. Each solvent was then evaporated by using electric fan until dryness.

The products used from commercial preparations were

\section{1-Natcom 40\%}

Contains: $40 \%$ Jojoba oil $+59 \%$ mineral oil $+1 \%$ garlic oil

\section{2- Tresser $\mathbf{2 4 \%}$}

Contains: $24 \%$ spinosad (Biocontrol agent)

\section{3-Diazinox $5 \%$ granules}

Cotains: $5 \%$ Diazinon, organophosphorous insecticide

\section{Field design experiments}

Field experiments were conducted at the Experimental Farm of Agriculture Faculty at Moshtohor, throughout the second week of April, 2009 for the highest natural infestation with S. cretica Awadallah, 1974 and Shalaby, 1996). Approximately 1/6 feddan was chosen to be sown with Giza 2 variety of maize. The area was divided into plots $3 \times 2.5$ meters. Each plot contained 5 rows at a distance of $70 \mathrm{~cm}$. Each of the assayed materials were applied on 4 replicates per treatment, the normal agriculture practice were followed plantations were arranged in complete randomized block design.

Application of the assayed treatments was done in the whorl of each plant by using a one liter sprayer and unfilled teaspoon (approx. $2 \mathrm{gm}$ ) for Diazinox granules $(1 / 2 \mathrm{Kg} /$ Feddan). Spraying of each treatment directly $16 \& 23$ days after sowing, respectively. 
The effect of plant extracts and preparations on infestation by $S$. cretica eggmasses, larvae, perforated leaves and dead hearts were estimated. At harvest time (120 days) after sowing ears were weighed and adjusted to find out the yield (ardab / feddan).

Finally, the percentage of reduction due to treatments compared to control were calculated.

Correlation coefficient between yield and $S$. cretica traits (average counts of egg-masses, larvae, plants containing perforated leaves and dead hearts) were calculated according to Snedecor and Cochran (1980).

\section{RESULTS AND DISCUSSION}

\section{Results of experimental field}

\section{a . Average number of egg masses}

Data in Table (1) clearly showed that, all treatments caused, significant reductions in the number of $S$. cretica egg-masses. The untreated plants harboured the highest number being 36 egg-masses / 40 plants. The highest efficacy obtained from treatment with Natcom 40 and Tresser formulate being 3 egg-masses / 40 plant, causing $91.6 \%$ reduction than control for both, followed insignificantly by Dodnia extract in acetone (4 egg-masses / 40 plants) as $88.8 \%$ reduction than control. Treatments including pulp of sour orange extract in petroleum ether $\&$ in water, dodnia extract in water and pulp of sour orange extract in acetone achieved intermediate efficacy in which, the egg-masses were $8,10,12$ and 14 egg-masses / plants as 77.7, 72.2, 66.6 and $61.1 \%$ reduction than control, respectively. On the contrary, the least effective treatments was the recommended chemical pesticide (Diazinox) and dodnia extract in pertolum ether ( 47.2 and $44.4 \%$ reduction, respectively)

\section{b- Larval count}

The number of larvae were counted in the untreated maize plants -randomizly collected - harbouring, significantly, the highest S. cretica larval counts 58 larvae / 25 plants were recorded in the control. The severest reduction (82.7\%) occurred in plants treated with pulp of sour orange extracted in petroleum ether and dodnia extract in water with average of 10 larvae / 25 plants. Efficacy of sour orange extracted in acetone \& water and Diazinox ranked the second and the third level in efficacy being 72.4 and $68.9 \%$ reduction with averages of 16 and 18 larvae / 25 plants, respectively. The remaining treatments showed an intermediate reduction and may be arranged descendingly as follow, Natcom 40, Tresser and dodnia extract in acetone 20, 21 and 21 larvae / 25 plants. On the contrary, dodnia extract in petroleum ether resulted in the 
least efficacy reduction in the number of larvae, achieving $37.9 \%$ reduction than control.

\section{c- Perforated leaf plant}

The highest average count of plants containing perforated leaves was in untreated plants (50 plants). While, pulp of sour orange extracted in petroleum ether and Natcom 40 caused the highest efficacy having one perforated leaf plant only / 50 plants as $98 \%$ reduction than control. Pulp of sour orange extracted in acetone, Tresser formulation, dodnia extracted in petroleum ether, pulp of sour orange extracted in water and dodnia extracted in acetone ranked intermediate positions in number of plants containing perforated leaves. Treatments with them resulted in 96, 96, 96, 94 and 92\% reduction, respectively. The least effective materials were Diazinox and dodnia extracted in water causing 88 and $80 \%$ reduction than control, respectively, Table (1).

\section{d- Dead heart plants}

As for the dead heart plants the data in the same table cleared that, the materials which achieved the lowest number of plants containing perforated leaves were almostly the same in the dead hearted as it is considered the main symptom for $S$. cretica infestation.

The materials could be divided into 2 groups, the first one including pulp of sour orange extracted in water \& pertrolum ether, Natcom 40 and Tresser formulation achieving one dead heart plant as $96 \%$ reduction than control. Followed by dodnia extract in petroleum ether ( 3 dead heart plants, $88 \%$ reduction than control). While, the second group including dodnia extracted in water, Diazinox, dodnia extracted in acetone and pulp of sour orange extract in acetone being $(6,7,8,8$ plants as 76,72 , $68,68 \%$, reduction than control, respectively).

\section{e- Dry ears yield}

All treatments caused increasing in the harvest weight of ears, especially those of Natcom 40 and Tresser formulation which achieved the highest yield (26.7 ardab / feddan) as $134.21 \%$ increasing than control, followed by treatments with pulp of sour orange extracted in water \& petrolum ether which achieved 24.8 and 22.9 ardab / feddan, respectively. The remaining 5 treatments took different positions among the mentioned groups of high and less efficacy which may be arranged descending order according to the obtained yields as follows: Diazinox, dodnia extracted in petrolum ether water $\&$ acetone and pulp of sour orange extracted in acetone $(19,16.2,13.3$, 12.4 and 12.4) ardab / feddan as $66,42.1,16.6,8.7$ and $8.7 \%$ increase than control, respectively. 


\section{The chemical components of tested plants}

\section{D. viscosa}

Leaves of $D$. viscosa L. were extracted with different organic solvents and phytochemical analysis showed the presence of glycosides, terpenes, flavones, and steroids, Dodonic acid was isolated and confirmed from the ether extract of the aerial parts of the plant. -Sitosterol was also present in the hexane extract of the plant material. Alcoholic extract of leaves showed the presence of quinonoid compounds whereas 5,7,3,4-tetrahydroxy flavone.

\section{C. aurantium v. amara}

Three active components were identified by bioassay-guided fractionation of bitter orange ( $C$. aurantium L.) they were identified as 7-methoxy-8-(3'-methyl-2'butenyl)-2H-1-benzopyran-2-one (osthol), 4-methoxy-7H-furo[3,2-g]benzopyran-7-one

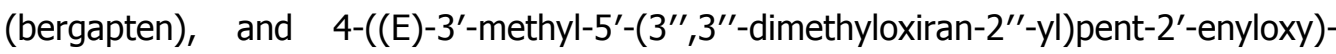
7H-furo[3,2-g][1]benzopyran-7-one (6', $7^{\prime}$-epoxybergamottin) Siskos et al (2008).

\section{Correlation coefficient}

Data in Table (2), showed the correlation coefficients of each average count of egg-masses and larvae of $S$. cretica also, number of plants containing perforated leaves and dead hearted plants. In which there were significant negative correlation values between yield and each of $S$. cretica traits (number of egg-masses, larvae, plants containing perforated leaves and dead hearts), revealing that the decrease in such traits resulted in increase in the grain yield.

These results may be considered in harmouny with those previously obtained by Hendy, (1994) examined the toxic activity of hexan and chloroform dodonia extract against Spodoptera littoralis larvae in which they achieved $50.6 \%$ as percentage mortality. It was found also that the percentage mortality reached $100 \%$ for the treated population after 12,17 days as a result of hexan and chloroform dodonia extracts, respectively. The author recorded decrease in pupal weight and percentage malformation. Also, there was decrease in adult emergence being $60 \%$, percentage pupation and number of egg deposited were decreased Finally, the authors stated that dodonia had a repellent effect on $S$. littoralis adults.

Also, Siskos et al., (2008) found that the $6^{\prime}, 7^{\prime}$-Epoxybergamottin - one of the components of bitter orange - was toxic when tested individually, while bergapten and osthol were found to act synergistically to $6^{\prime}, 7^{\prime}$-epoxybergamottin. Epoxybergamottin was toxic when tested individually, while bergapten and osthol were found to act synergistically to $6^{\prime}, 7^{\prime}$-epoxybergamottin in fruit peel petroleum ether extract, silica gel fractionation of the extract yielded a fraction that inflicted up to $96 \%$ mortality to adults of the olive fruit fly Bactrocera oleae. 
Table 2. Simple correlation coefficient between yield and each of traits average counts of egg-masses, larvae, plants containing perforated leaves and dead hearts) after treatment with different plant extracts in corn fields.

\begin{tabular}{|l|c|}
\hline \multicolumn{1}{|c|}{ Traits } & Correlation coefficient $(r)$ \\
\hline Egg-masses & $-0.61431^{* *}$ \\
\hline No. of larvae & $-0.36588^{*}$ \\
\hline No. of plants containing perforated leaves & $-0.49273^{* *}$ \\
\hline No. of dead heated plants & \\
& $-0.70834^{* *}$ \\
\hline
\end{tabular}




\section{REFERENCES}

1. Afifi, F.A., A.M. Hekal and M. Salem. 1988. Fenugreek seed extracts as protectants of wheat grains against certain stored product insects. Annals of Agric. Sci., Fac. Agric., Ain Shams Univ., Cairo, Egypt, 33(2): 1331 - 1344.

2. Amany, S. El-Hefny and SH.S. Yacoub. 2008. Evaluation of certain aqueous plant extracts as antifeedants against Spodoptera littoralis (Boisd.) and its biological aspects Egypt. J. Res., 86(6).

3. Awadallah, W.H. 1974. Biological studies on corn borers in Egypt, Ph.D. Thesis Fac. Of Agric. Ain Shams Univ., 176 pp.

4. Awadallah, W.H., A.F. Lutfallah and Y.H. Fayed. 1984. |Effect of spraying corn with water extracts of certain aromatic plants on the population of Sesamia cretica Led. and the main predators in corn fields, Agric. Res. Rev. 62(1): $47-52$.

5. Hendy, Z.H., G. El- Saadany, A. Sharaby, E.A. Omer and S. Abd-El-Aziz. 1994. Biological activity of essential oil of Dodonaea viscosa plant against the cotton leafworm, Spodoptera littoralis boisd, Conference of Agricultural Development Research, Cairo (Egypt), 20-22 Dec.

6. El-Sayed, E.I. 1982. Neem A. indica seeds as antifeedant and ovipositional repellent for the Egyptian cotton leafworm Spodoptera littoralis (Biosd.) Bull. Ent. Soc. Egypt, Econ. Ser., (49): 49 - 58.

7. Emara, M.M., A.G. El-Sisi and S.A. Mahmoud. 1994. Formulation and evaluation of certain local natural products against Varroa, a mite infesting bee colonies. J. Agric. Sci. Mansoura Univ., 19(5): $1843-1850$.

8. Shalaby, G.A.E.M. 1996. Studies on certain maize pests in Kafr El-Sheikh Governorate. M. Sc. Thesis, Fac. of Agric., Zagazig Univ.

9. Siskos, E. P. , B. E.Mazomenos and M. A. Konstantopoulou. 2008. Isolation and Identification of Insecticidal Components from Citrus aurantium fruit peel extract J. Agric. Food Chem., 56 (14), pp 5577-5581

10. Snedecor, G.W. and W.G. Cochran. 1980. Statistical methods $7^{\text {th }}$ edition, lowa State University Press. Ames, lowa.

11. Yacoub, Sh. S. 2006. Efficacy of some plant extracts in controlling Sesamia cretica Led. and Ostrinia nubilalis (Hubn.) in maize fields. Ph. D Thesis, Fac of Agric., Benha University, Egypt.

12. Yacoub, SH.S. and Amany S. El-Hefny. 2008. Toxic activity of six plant water extracts against Spodoptera littoralis (Lep., Noctuidae) in the laboratory Egypt. J. Res., 86(2). 


\section{تقييم بعض المركبات من اصل نباتى تحت الظروف الحقلية فى مكافحة دودة القصب الكبيزة على نباتات الأرة}

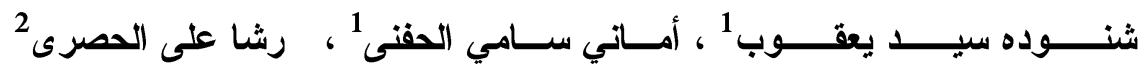

$$
\text { r ا . . كعلة بحوث وقـاية النباتات - مركز البحــوث الزراعيــة - الدقى }
$$

تم تقييم بعض مستخلصات نبات النارنج و الديدونيا فى كل من الماءو الميثانول و الاسيتون

وبعض المركبات الاخرى من اصل نباتى ضد دودة القصب الكبيزة فى حقول الذرة الثامية خلال

العروة الصيفية المبكرة لموسم 2009. و أوضحت النتائج ان مركب ناتكوم 40 مستحضر زبند زيت الهو هوبا و الترسير 24\% حققا أفضل النتائج حيث بلغت نسبة النقص فى تعداد لطع البيض بمعدل 3 لطعة / 40 نبات لكليهما. بينما حقق المستخلص المائى لنبات الديدونبا ومستخلص النارنج بالبتروليم ايثز اعلى نقص فى تعداد اليرقات حيث بلغت 10 يرقات /25 بنات بلنات بمعدل نقص عن المقارنة 82.7\% لكليهما.

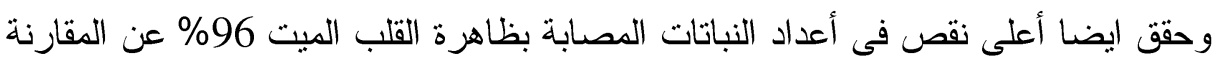

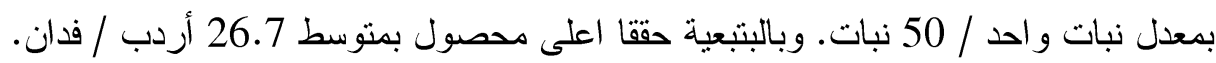
و أوضحت النتائج ان هناتك ارتباط معنوى سالب بين المحصول ومظاهر الاصابة الحشرة على نباتات

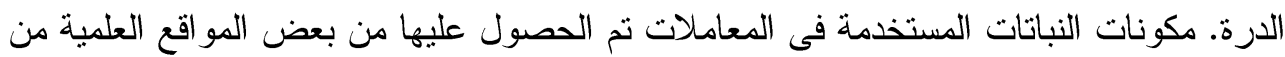
الثبكة الدولية للمعلومات. 